\title{
Clinical and pathological features of a non-crystalline form of Schnyder corneal dystrophy
}

\author{
Nicole Arnold-Wörner • David Goldblum • \\ André R. Miserez • Josef Flammer • Peter Meyer
}

Received: 12 September 2011 /Revised: 10 February 2012 / Accepted: 18 February 2012 / Published online: 14 March 2012

(C) Springer-Verlag 2012

\section{Introduction}

Schnyder corneal dystrophy (SCD) is a rare progressive bilateral disorder of the cornea resulting from an abnormal deposition of (un)esterified cholesterol and phospholipids throughout the cornea. SCD is an entity characterized by a varied spectrum of corneal changes, a fact that may cause difficulties for making the correct diagnosis. In previous publications, the clinical appearance has been described as a deposition of crystals predominantly located in the anterior stroma, accompanied by an arcus lipoides and a stromal haze [1]. However, Weiss et al. demonstrated that corneal crystals are found in only $54 \%$ of patients $[2,3]$, while the other patients presented with a disc-like central corneal opacity without subepithelial cholesterol crystals. Abnormal lipid deposition has been seen throughout the corneal stroma, but also in the basal epithelium, in the Bowman's layer and occasionally within endothelial cells [2].

The authors have full control of all primary data, and agree to allow Graefe's Archive for Clinical and Experimental Ophthalmology to review their data upon request.

N. Arnold-Wörner $(\bowtie) \cdot$ D. Goldblum $\cdot$ J. Flammer $\cdot$ P. Meyer

Department of Ophthalmology, University Hospital Basel,

Mittlere Strasse 91,

4031 Basel, Switzerland

e-mail: arnoldn@uhbs.ch

A. R. Miserez

Diagene Laboratories Inc.,

Kaegenstrasse 17,

4153 Reinach, Switzerland

A. R. Miserez

University of Basel,

Basel, Switzerland
We present a patient with a non-crystalline form of SCD. We describe clinical aspects, and demonstrate light and electron microscopic features of this disease.

\section{Case report}

An 82-year-old female patient presented with progressive bilateral corneal opacification (Fig. 1a). The best-corrected visual acuity was 0.4 bilaterally. Both corneas displayed central corneal opacity with a marked arcus lipoides. The corneal thickness was slightly elevated, and the corneal sensitivity was reduced bilaterally. Both lenses also showed a progressive nuclear cataract. The examination of the fundus was inconspicuous.

In the personal medical history, arterial hypertension as well as depression, but no systemic lipometabolic disorder was reported. The family history revealed the presence of cloudy cornea in the father as well as the daughter of the patient.

To improve the vision of the patient, a PKP was performed followed by cataract surgery 7 months later.

\section{Results}

The sections of the corneal button were analysed with light and electron microscopy. The histology revealed five to six layers of corneal epithelium cells with a slightly irregular thickness (Fig. 1c). Basal epithelial cells showed mild vacuolization of the cytoplasm. Analogous vacuoles of smaller size were also found in the Bowman's layer with electron microscopy (Fig. 2a). The central part of the cornea contained grouped rounded intra- and extracellular holes throughout the thickness of stroma (Fig. 1b, Fig. 2b). In 
Fig. 1 a Clinical appearance of the cornea with dense central opacity and marked arcus lipoides. b Light microscopy of the cornea with grouped vacuoles in the stroma (HE). c Higher magnification of the cornea shows small vacuoles in the epithelium and the Bowman's layer and larger ones in the stroma (PAS). d The Descemet membrane appears normal; the endothelial cells contain small vacuoles, and are sligthly flattened and diminished in number (HE)



b

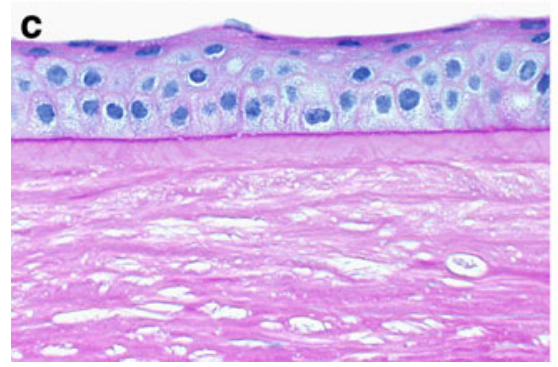

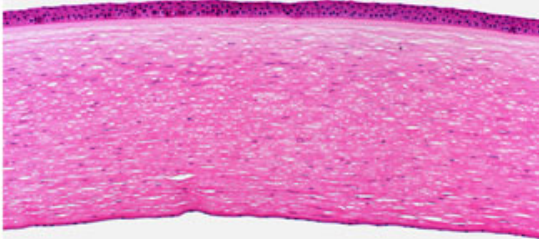



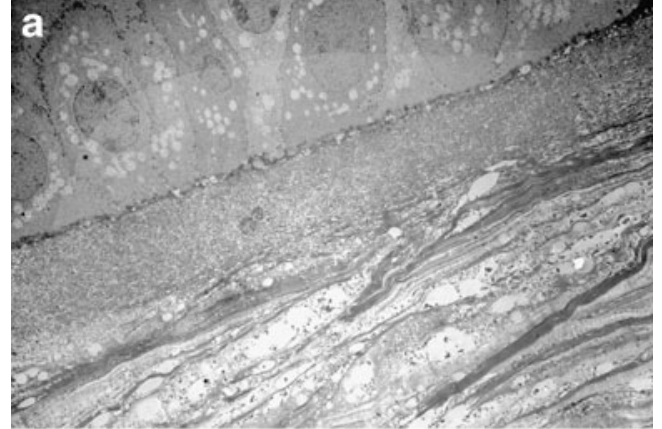
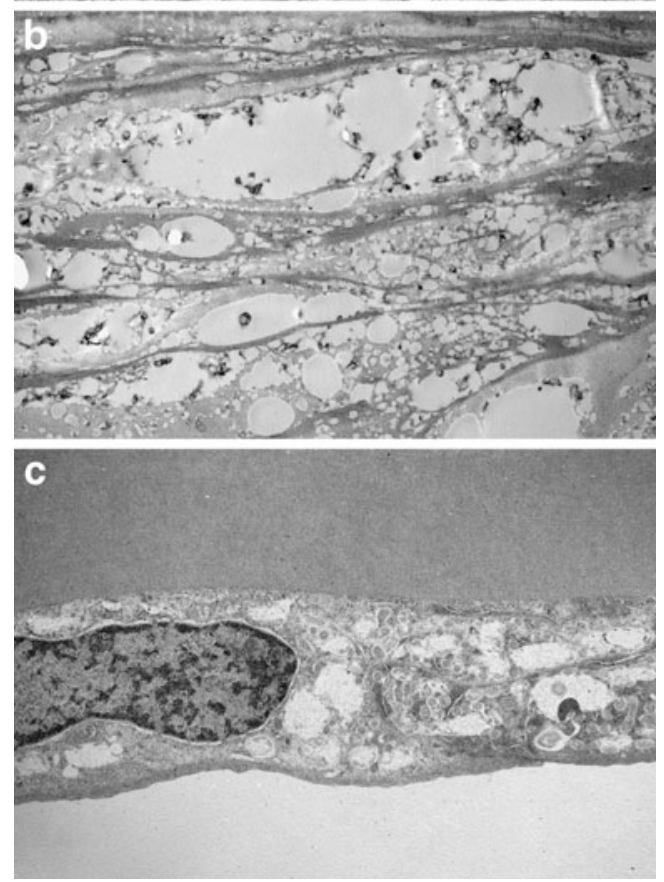

Fig. 2 a Electron microscopy of the cornea demonstrates vacuoles in epithelium, Bowman's layer and stroma. b Elongated vacuoles and angular defects of the corneal stroma (EM). c Lipid deposits in the stroma and in the endothelial cells of the cornea (EM) addition, keratocytes were less numerous in this affected central part of the cornea. These stromal abnormalities were less pronounced in the peripheral part of the cornea. The Descemet membrane appeared to be normal, while endothelial cells also contained small vacuoles and appeared slightly flattened and diminished in number (Fig. 1d, Fig. 2c). Due to the embedding of the specimen, any fatty material was removed from these abnormalities.

Genetic analyses revealed a heterozygous missense mutation at a highly conserved amino acid position [4] in the UbiA prenyltransferase domain-containing protein 1 (UBIAD1) gene on chromosome 1p36.3 (OMIM \#121800).

\section{Discussion}

The autosomal-dominant SCD was first mentioned by van Went and Wibaut in 1924 [5], and the disease was described in more detail by Schnyder in 1929 [6]. The disease affects both sexes equally and is seen in several ethnic groups in the world.

Most authors describe clinical appearance of the corneal dystrophy as a deposition of crystals in the anterior stroma early in life, with subsequent appearance of a dense corneal arcus lipoides in combination with a stromal haze. However, there were also reports of patients lacking such crystal deposits. Weiss showed presence of the crystalline form in $54 \%$ of all cases, the remaining patients presented with a central disc-like corneal opacity leading to a midperipheral stromal haze and an early dense arcus lipoides [2, 3]. Already in 1968, Delleman and Winkelman described a case of SCD without crystals; furthermore, they mentioned that not only the anterior corneal layers but also the deeper stromal layers could be involved [7]. 
Both our patient and her daughter suffered from a noncrystalline form of SCD. The origin of the reported corneal opacity in the patient's father remains unknown. Light and electron microscopy in our patient showed small vacuoles not only in the anterior stroma, but throughout the cornea except the Descemet membrane.

Although Schnyder crystalline corneal dystrophy has been the more commonly used name for this entity, this term has led to confusion in diagnosis. Consequently, in the new IC3D classification of the corneal dystrophies, the name Schnyder corneal dystrophy is the preferred name [8].

The exact pathogenesis of SCD remains unknown, it is assumed that a localized defect of lipid metabolism is involved in the pathway $[2,9]$. Crispin postulated a temperature dependent enzyme defect, since the first cholesterol deposition occurs in the axial/paraxial cornea, the coolest part of the cornea [10]. The causative gene for SCD, UBIAD1, encodes a prenyltransferase that plays a role in sterol metabolism $[9,11]$.

Several diseases leading to the deposition of lipid material into the cornea have to be ruled out in the differential diagnosis. These are mainly systemic diseases with involvement of the cornea. The spectrum includes hyper- and hypolipoproteinemias (e.g., lecithin-cholesterol acyltransferase (LCAT)), liposomal accumulation disease, and druginduced lipid disorders. In contrast to these systemic diseases, lipid deposition or Bietti's crystalline dystrophy are local defects of the corneal lipid metabolism. The diagnosis of SCD in our patient was genetically confirmed by the presence of a mutation in the UBIAD1 gene.

\section{Conclusion}

For the correct diagnosis of SCD, it is important to remember that patients have crystalline corneal deposits in only half of the cases. The corneal changes may be seen throughout the cornea and not only in the anterior stroma.
Financial interest None

\section{References}

1. Paparo LG, Rapuano CJ, Raber IM, Grewal S, Cohen EJ, Laibson PR (2000) Phototherapeutic keratectomy for Schnyder's crystalline corneal dystrophy. Cornea 19:343-347

2. Weiss JS (2007) Visual morbidity in thirty-four families with Schnyder crystalline corneal dystrophy (an American Ophthalmological Society thesis). Trans Am Ophthalmol Soc 105:616-648

3. Weiss JS (2009) Schnyder corneal dystrophy. Curr Opin Ophthalmol 20:292-298

4. Nickerson ML, Kostiha BN, Brandt W, Fredericks W, Xu KP, Yu FS, Gold B, Chodosh J, Goldberg M, da Lu W, Yamada M, Tervo TM, Grutzmacher R, Croasdale C, Hoeltzenbein M, Sutphin J, Malkowicz SB, Wessjohann L, Kruth HS, Dean M, Weiss JS (2010) UBIAD1 mutation alters a mitochondrial prenyltransferase to cause Schnyder corneal dystrophy. PLoS One 5:e10760

5. van Went J, Wibaut F (1924) En zeldzame erfelijke hoornvliessandoening. Niederl Tijdschr Geneesks 68:2996-2997

6. Schnyder WF (1929) Mitteilung über einen neuen Typus von familiärer Hornhauterkrankung. Schweiz Med Wochenschr 10:559-571

7. Delleman JW, Winkelman JE (1968) Degeneratio corneae cristallinea hereditaria. A clinical, genetical and histological study. Ophthalmologica 155:409-426

8. Weiss JS, Moller HU, Lisch W, Kinoshita S, Aldave AJ, Belin MW, Kivelä T, Busin M, Munier FL, Seitz B, Sutphin J, Bredrup C, Mannis MJ, Rapuano CJ, Van Rij G, Kim EK, Klintworth GK (2008) The IC3D classification of the corneal dystrophies. Cornea 27(Suppl 2):S1-S83

9. Weiss JS, Kruth HS, Kuivaniemi H, Tromp G, White PS, Winters RS, Lisch W, Henn W, Denninger E, Krause M, Wasson P, Ebenezer N, Mahurkar S, Nickerson ML (2007) Mutations in the UBIAD1 gene on chromosome short arm 1, region 36, cause Schnyder crystalline corneal dystrophy. Invest Ophthalmol Vis Sci 48:5007-5012

10. Crispin S (2002) Ocular lipid deposition and hyperlipoproteinaemia. Prog Retin Eye Res 21:169-224

11. Orr A, Dubé MP, Marcadier J, Jiang H, Federico A, George S, Seamone C, Andrews D, Dubord P, Holland S, Provost S, Mongrain V, Evans S, Higgins B, Bowman S, Guernsey D, Samuels M (2007) Mutations in the UBIAD1 gene, encoding a potential prenyltransferase, are causal for Schnyder crystalline corneal dystrophy. PLoS One 2(8):e685 